\title{
OA13.04. Physical health benefits of health Qigong and Energize programs in American elementary school classrooms
}

\author{
C Wang $^{1 *}$, D Seo ${ }^{1}$, R Geib $^{2}$, N Wroblewski ${ }^{3}$, M Van Puymbroeck', L Kolbe ${ }^{1}$ \\ From International Research Congress on Integrative Medicine and Health 2012 \\ Portland, Oregon, USA. 15-18 May 2012
}

\section{Purpose}

With the increasing use of complementary and alternative medicine, mind-body exercises (i.e., Tai Chi, Yoga, and Qigong) have become more popular in the United States. In particular, numerous recent investigations have suggested the positive benefits of Qigong for cardiovascular fitness, musculoskeletal conditions, and stress. However, such research is largely limited to adults and the elderly. Few studies have explored the benefits of Qigong in the pediatric population. Thus, the purpose of this study is to investigate: (1) whether Health Qigong is effective, and (2) how effective it is compared with conventional exercise among elementary school children.

\section{Methods}

A pre- and post-test quasi-experimental design was used to assess the effects of three different modes of exercise: (1) aerobic exercise (Energize), (2) mind-body exercise (Health Qigong), and (3) conventional physical education (PE) activities, in terms of improving health during a 16week intervention, as measured by Heart Rate (HR), Sitand-Reach (SR), and Body Mass Index (BMI) in children.

\section{Results}

One hundred and five children provided valid data from two elementary schools in Southern Indiana. Of the 105 students, 57 (35.2\%) were boys. The average age was 9 years old. The repeated measures analyses of variance revealed a significant decrease in $\mathrm{HR}(\mathrm{F}=70.54, \mathrm{p}<.001$, $\eta 2=.409)$, SR $(\mathrm{F}=11.68, \mathrm{p}<.001, \eta 2=.103)$, and $\mathrm{BMI}$ $(\mathrm{F}=41.97, \mathrm{p}<.001, \eta 2=.292)$. In particular, BMI decreased more quickly from the Health Qigong group,

${ }^{1}$ Indiana University Bloomington, Bloomington, USA

Full list of author information is available at the end of the article with a mean change of $0.698(\mathrm{p}<.001)$, than the Energize $(0.197, \mathrm{p}<.05)$ and the PE group $(0.224, \mathrm{p}<.05)$.

\section{Conclusion}

Health Qigong can be as effective as aerobic exercise and physical education activities in reducing $\mathrm{HR}$ and increasing SR among elementary school children. Given the significant reduction in BMI, Health Qigong should be further investigated on a possible mechanism to help lose body weight.

\section{Author details}

${ }^{1}$ Indiana University Bloomington, Bloomington, USA. ${ }^{2}$ Indiana University School of Medicine, Terre Haute, USA. ${ }^{3}$ Monroe County YMCA, Bloomington, USA.

Published: 12 June 2012

\section{doi:10.1186/1472-6882-12-S1-052}

Cite this article as: Wang et al:: OA13.04. Physical health benefits of health Qigong and Energize programs in American elementary school classrooms. BMC Complementary and Alternative Medicine 2012 12(Suppl 1): O52.

Submit your next manuscript to BioMed Central and take full advantage of:

- Convenient online submission

- Thorough peer review

- No space constraints or color figure charges

- Immediate publication on acceptance

- Inclusion in PubMed, CAS, Scopus and Google Scholar

- Research which is freely available for redistribution 